Ankara Üniversitesi

SBF Dergisi,

Cilt 69, No. 3, 2014, s. 569 - 594

\title{
A SOCIOLOGICAL INQUIRY ON WOMEN'S WELL-BEING AND WAGED-WORK
}

\author{
Dr. Esra Sarıŏlu \\ Yeditepe Üniversitesi \\ Sosyoloji Bölümü
}

Kadınların Refahı ve Ücretli Emek Üzerine Sosyolojik Bir İnceleme

\section{Öz}

$\mathrm{Bu}$ makale, kadın ücretli emeği üzerine olan araştırma ve teoriyi ve bunların özellikle kadınların refahının sosyolojik olarak anlaşılmasına ne türden katkılar yaptığını inceliyor. Kadının ücretli emeği ve refahı üzerine olan incelemeler, ilhamını kadınların son yıllarda küresel yeniden yapılanma sonucu emek gücüne dahil edilmesinden alıyor. Bu yazıda, işçi sınıfından kadınların rehafina ilişkin farklı teorik yaklaşımları temsil eden dört temel araştırma alanını inceliyorum: kadının kapasitesinin gelişimine odaklanan insani kalkınma yaklaşımı; imtiyazsız kadın işgücünün küresel yeniden üretimi ile ilgilenen yapısal-ilişkisel perspektif; kadın işçilerin öznelliklerini iktidar ilişkileri bağlamında değerlendiren post-yapısalcı feminist yaklaşım; ve son olarak küreselleşme ile birlikte ortaya çıkan iktidar ilişkilerine olduğu kadar, kadınlar için doğan firsatlara da dikkat çeken toplumsal cinsiyet ve küreselleşme literatürü. Kadının refahı ve ücretli emek arasındaki ilişki tartışılması büyük bir araştırma alanına oluşmasına imkan verdi. Ancak varolan literatür refah kavramının duygusal boyutlarını yeterince incelemiyor. Bu makale, duygu üzerine yapılmış sosyolojik araştırmaların potansiyel katkılarını işaret ederek kadın işçiler ve refah arasındaki ilişkinin tartışılmasına yeni bir boyut ekliyor.

Anahtar Sözcükler: Kadın, ücretli emek, refah, cinsiyet, küresel yeniden yapılanma

\begin{abstract}
This article reviews research and theory on women's waged-work with a particular focus on its contributions to sociological understandings of women's well-being. Sociological inquiry on women's wellbeing and waged-work is motivated by the most critical issue of the recent incorporation of women into the labor force as a result of global restructuring. I examine the recent research on women's waged-work within four major areas of inquiry, chosen because they represent distinct theoretical approaches to women's wellbeing: the human development approach focuses on enhancing the capabilities of women, the structuralrelational perspective is concerned with the global reproduction of an underprivileged women workforce, the post-structuralist feminist approach investigates women workers' subjectivities in relation to power relations, and gender and globalization literature addresses opportunities for women as well as power relations emerging with globalization. The question of women's well-being and waged work has inspired a tremendous amount of research, but the existing research does not sufficiently recognize the emotional dimensions of well-being. This article adds a new dimension to the inquiry on women's well-being and wage work by highlighting the potential contributions of sociological study on emotions.
\end{abstract}

Keywords: Women, waged-work, well-being, gender, global restructuring

\footnotetext{
* Makale geliş tarihi: 22.08.2014
}

Makale kabul tarihi: 16.09.2014 


\section{A Sociological Inquiry on Women's Well-Being and Waged-Work}

\section{Introduction}

This article undertakes a critical analysis of the question regarding the relationship between women's well-being and waged-employment. The question was first posed by F. Engels (1844) in the 19th century. In the early period of industrialization when European populations increasingly became part of the proletariat, Engels was certain that women's incorporation into waged-work would facilitate their own emancipation. For one thing, women would march from their homes to factories, asserting their political solidarity with other workers to achieve the historical goal of subordinate classes. ${ }^{1}$

Almost a century after Engels's projection, the labor force participation trend for women gained momentum in developed countries, and beginning from the mid-1970s, working class women in the developing regions of the world were also increasingly integrated into the labor force as waged-workers ${ }^{2}$ due to complex transformations in the political economy, the unprecedented mobility of capital on a world scale, advanced technology, the dispersal of production to the developing countries, increasing mobility of labor, structural adjustment programs, transformation of nation-state sovereignty, marketization of national economies and etc.,-- which are all analyzed under the rubric of global restructuring. Global restructuring has not only precipitated the formation of a highly feminized labor force but also made Engels' question more pressing for scholars concerned with women's liberation.

\footnotetext{
${ }^{1}$ Engels identified the proletariat mostly with the factory workers of the 19th-Century.

${ }^{2}$ This study concurs with the feminist perspective that women have always been integral to the economy and the work they do (both at home and outside of home) is central to societies. Nevertheless, it aims to explore how existing literatures conceptualize the impact of women's waged-work on their well-being. In this framework, not only do I analyze different discourses of well-being but also investigate women workers' complex experiences shaped by waged-work.
} 
Paradoxically, the further the proletarianization trend extends in developing economies, in association with the increasing reliance on women particularly as providers of cheap labor, the fewer scholars adhere to the sanguine projection of Engels. Underlying this disenchantment is that an inescapable tendency toward proletarianization has proven to be highly doubtful because the recent industrialization processes in the developing countries has barely created the anticipated the formal proletariat. Instead, the global restructuring precipitates the formation of a highly segmented and heterogeneous labor force (Portes, 2004; Sassen, 2008, Standing, 2009, Whitson, 2010). In stark contrast to the formal proletariat, the highly feminized labor force of the global era lacks the resources to increase its bargaining power since with the increasing mobility of capital, established labor relations have been dismantled, labor unions have lost much of their power, protected industrial sectors that used to employ most of the formal labor force have downsized, and employment relations have been increasingly causualized. Numerous scholars argue that the current era of globalization has indeed had a deleterious effect on women's income opportunities and conditions of work in both developed and developing economies (Beneria, 2003; Peterson, 2003; Pearson, 2004; Seguino, 2006).

Within this context, socialist-feminists contend that 'The Engelian Myth' -a term coined by Pearson (2004) and which assumes women's emancipation lies in their incorporation to the labor force- has collapsed, whereas liberal approaches remain optimistic about the implications of women's incorporation to labor force. By placing a constructive emphasis on women's incremental gains associated with employment, such as women's increasing autonomy, work-related entitlements, housing, education, and reproductive choices, liberal approaches lay out potential opportunities that are underestimated in classbased/structural explanations.

A glimpse of the controversy between Marxist and liberal approaches on the question regarding the relationship between women's waged-work and their well-being offers an entry point into this field of inquiry. The contention among different currents of thought as well as the complexity of global restructuring poses the need to examine the relationship between waged-work and women's well-being and the opportunity to recast the analysis in terms of historically specific dimensions of global restructuring process. Of particular importance is the examination of the impact that globalization has on women incorporation into the lower segments of the labor market. Focusing on women located at the lower echelons of the labor market raises particular questions that define the boundaries of the field of inquiry: Does this recent incorporation merely serve the interests of capital by transforming women into cheap labor, or does it open up novel possibilities for women by increasing their bargaining 
power in households, workplaces, and labor markets? How does women's integration into the labor force refigure gender hierarchies? What are the implications of race, ethnicity, marital status, and age for women's integration into labor force?

The distinct field of inquiry on women's well-being and waged-work crosscuts several areas of study: development studies, structural-relation perspective on gender, post-structural feminist analysis of the labor process, and the globalization and gender literatures. Below, I provide a review of the literature on women's well-being and waged-work through a critical engagement with each scholarly area. The concept of well-being offers a suitable lens to analyze the ways in which social scientists evaluate the consequences of women's incorporation into wage-work. Here, I take wellbeing as a broad concept distinct from subjective well-being. While subjective well-being refers to cognitive and emotional evaluation of individuals' quality of their lives, the concept of well-being is not necessarily concerned with psychological dimensions but allow us to assess social and cultural effects of social structures and hierarchies on raced, classed, gendered groups of individuals. The concept of well-being is elusive but fits neatly into each scholarly approach to women's liberation. On the one hand, each area of study has a normative (feminist) orientation towards diminishing the conditions of women's subordination. On the other hand, the flexibility of the term helps capture different theoretical formulations such as emancipation, empowerment, and autonomy.

\section{Present State of the Field}

Differences in explanatory emphasis and conceptual repertoire notwithstanding, contemporary inquiries on the relationship between women's well-being and waged-work share two common features. First, studies have shifted away from an economistic approach and adopted more embedded forms of analyses incorporating historical, political, and discursive contexts. Secondly, inquiries on women's waged-work have moved away from universalizing methodologies and have instead become more attentive to multilayered contextual analyses that "reveal how the particular is often universally significant without using the universal to erase the particular or positing an unbridgeable gulf between the two terms (Mohanty, 2003:503)."

By employing the term economistic, I refer to the economizing logic of the structural-functionalist vantage points that rest on the assumption that one can deduce salient identities and interests from social structures or aggregate statistical data. Structural functionalist approaches, which differ from materialist approaches in emphasizing that interdependent social structures 
shape the society as a whole, tend to subscribe reductionist explanations of social phenomena. For instance, globalization and gender literatures borrow heavily from earlier scholarships on Women in Development (WID), Women and Development (WAD), and Gender and Development (GAD), and have previously shared those scholarships' economistic assumptions regarding women's interests. ${ }^{3}$ Most of the studies in this vein have tended to deduce women's interests from the ahistoric structures of capitalism, imperialism, and patriarchy. By extension, theses on exploitation, which uphold that industrialization creates a cheap female workforce, and marginalization, which maintains that industrialization excludes women from productive roles and confines them to the household or informal economy, predominated the early period. Nevertheless, beginning from the mid-1990s, by drawing on fields of ethnography, anthropology and post-structural feminist scholarship, globalization and gender scholars began to focus on the ways in which contradictory processes and unanticipated consequences of global processes shape women's contextually defined and historically changing interests.

Recent studies also criticize the predominance of universalizing methodologies in studying women's integration into the labor force on the grounds that these methodologies erase the particular and fail to give an account of how the particular and the universal are linked. Instead of assuming that women are a coherent group prior to their entry into development process, some compelling recent scholarship investigates "the real and concrete effects of global restructuring on raced, classed, national, and sexual bodies of women in workplaces, streets, households, cyberspaces, neighborhoods, prisons, and social movements (Mohanty, 2003: 525)." Post-structuralist feminists, for

\footnotetext{
${ }^{3}$ Women and Development (WID), Women and Development (WAD), and Gender and Development (GAD) are three interrelated but distinct fields of scholarship that investigate the complex relations between development studies and women's lives. Emerging in the early 1970s, the WID approach is based on the critique of development studies that omitted the role of women in society. The WID literature represents women as productive members of society. The major purpose of the proponents was to integrate women into the development process. The WAD perspective focuses on the relationship between women and development process rather than exclusively on strategies for the integration of women into the development process. Its point of departure is that women have always been integral to the economy and the work they do (both at home and outside of home) is central to societies. The GAD literature emerged in the 1980s as an alternative to WID and WAD. GAD is not interested in women per se but with the social construction of gender in relation to development process. For more details on WID,WAD and GAD see, for example, Rathgeber (1990); Razavi \& Miller (1995) and Tinker (1990).
} 
instance, challenge the idea that "women" refers to a shared essence or common identity. They argue for a historically contingent analysis of gender inequality dependent upon the changing configurations of power and hierarchy (Butler 1990; Scott 1992).

\section{Human Development Approach: Women's Capacities and Empowerment}

The human development approach, currently the predominant perspective within development studies, provides a normative framework for the evaluation and assessment of individual well-being. Scholars operating within the human development approach reject the simplistic correlation between the notion of well-being and the quantity of monetized economic activity. Instead, they advocate a novel framework for the analysis of wellbeing, which is reflected in the expansion of individual choices in ways that enable people to lead the lives that they value (Sen, 1988; UNDP, 2000).

Central to the notion of well-being is Amartya Sen's (1999) capabilities approach. Concerned with enhancing human freedom, Sen argues that wellbeing should be evaluated in terms of the expansion of the capabilities and abilities to make choices. With respect to women, Sen states that women's well-being is strongly influenced by their ability to earn an independent income, to find employment outside the home, to have ownership rights, literacy, be educated, and to be participants in decisions inside and outside of the family. Accordingly, he contends that these abilities are aspects of agency insofar as women are doing things and making choices that then give them voice, social standing, independence and empowerment (Sen, 1999)

Many of the empirical studies that have built upon this framework for assessing women's well-being relative to paid work combined the capability approach with empowerment literature. The latter is an immensely growing literature that explores the ways in which women are vested with power through globalizing processes and their local variations and contestations (for example, see Agarwal, 1997; Jeejebhoy and Sathar, 2001; Bespinar, 2010). Based on the basic premises of the capability approach, Kabeer $(1999,2001)$ offers a framework for empowerment, by which she refers to "the expansion in people's ability to make strategic life choices in a context where this ability was previously denied to them" (1999: 135). A growing number of focused ethnographies, drawing on Kabeer's insights, investigate multifaceted aspects of agency and the variety of choices women workers have in different settings (for example, see Razavi, 2007; Shin, 2008; Murphy-Graham, 2008). Studies in this vein identify the expanding range of women's choices, from marital 
options to education, and household decision-making, which have emerged as a result of employment.

Empirical analyses focusing on the range and quality of choices that women have as they engage in waged-work are heavily concentrated at the individual and household level (Malhotra, Schuler, and Boender, 2002). A theme widely reported in the literature is the pursuit by young women workers of greater autonomy and control over courtship and marriage decisions. Wage workers in rural Malaysia and Indonesia (Wolf, 1992), factory operatives in Sri Lanka (Lynch, 1999), and economic migrants in Shenzen, China (Clark, 2001), all use the enhanced autonomy stemming from wage earning to negotiate over desired partners, to postpone or evade arranged marriages, or to experiment with new styles of unsupervised romance and independent matchmaking. Similarly, studies that center on married women's enhanced autonomy explore the ways in which women exercise their agency through raising their voices in household decision-making processes such as household livelihood security (Kantor, 2009) income spending (Frankenberg \& Thomas, 2001), fertility (Mason \& Smith, 2000; Beutelspacher, Martelo \& Garcia, 2005) contraceptive use (Gage, 1995), and child health (Jejeebhoy, 2000).

The most cutting-edge empirical research investigates the empowerment effects at multiple levels by taking different socioeconomic and cultural conditions into consideration. Qualitative studies have acknowledged the impact of individual or household situations combined with institutional structures (Kabeer, 2001; Mayoux, 2001). In a comparative analysis across two countries, Kabeer (2001) explores the different ways in which women are integrated into garment industries as factory workers in Dhaka and Bangladeshi home-based workers based in London to examine the conditions under which women make strategic life-choices, or decisions that influence a person's life trajectory and subsequent ability to exercise autonomy. She demonstrates that the impact of women's access to waged work is not a uniform one, for women themselves are not a uniform category defined solely by their gender. For example, home-based workers in London are not able to exercise a major influence in shifting intra-household power inequalities due to the meagerness of the earnings and social isolation of their working conditions. Similarly, factory workers in Dhaka who get propelled into work by circumstances beyond their control are least likely to have experienced it as an expansion of their choices. However, Kabeer argues the majority of women factory workers who take up employment as a choice experience the transformatory potential of waged-work. Some women use their greater sense of self-reliance to take a stand against dowry arrangements and are determined to marry only those who ready to value them in a marriage as a partner. Some women use the improved 
credibility of their exit option to renegotiate the terms of their relationships, and in some cases even exercised those exit options such as divorce.

To recapitulate, the human development approach underlines women's agency on the basis of increasing the range of strategic options as a consequence of employment. However, as it fails to elaborate on divergence and conflict of interests among different groups/structures such as women, capital, family, market and etc., it subscribes into the trickle-down theory of economic growth, which predicts that the benefits of growth will eventually reach backward or disadvantaged regions within the country, just as it will reach poorer social classes. In that sense, the notion of empowerment rests on the unwarranted assumption that recent wave of marketization is relatively harmonious with women's interests.

\section{Structural Relational Perspective on Women's Work}

Empowerment, especially in the context of the capabilities approach, has gained wide recognition and legitimacy as a strategy of promoting women's well-being. Yet, at the same time, it has come under attack on the grounds that it fails to analyze the role of institutionalized power in causing or perpetuating inequalities. Scholars attentive to world-system analysis contend that the capability approach fails to address adequately the historical and structural roots of inequality (gender and class) as well as various relations of dependence (Hill, 2005; Feldman, 2005; Feldman \& Gellert, 2006). By deploying a structural-relational perspective, they argue that instances of women's empowerment through wage-work are bound to be partial and cannot be universalized given that capitalism as a world market phenomenon structurally creates marginal masses that cannot be integrated into a formal working class, that multiple forms of labor relations cannot fit into contractual wagedrelations, and that varied levels of coercion-based social conditions exist for women across the world. Of particular significance here is the structuralrelationality and simultaneous proliferation of waged and unfree/unpaid labor relations (Bennholdt-Thomsen, 1984; Mies, Bennholdt-Thomsen, and von Werholf, 1988; Caffentzis, 1999; Kapadia, 1995; Federici, 2008).

Informed by Marx's insight that contractual wage-relations are too costly for the accumulation of capital, and therefore the formal proletariat constitutes relatively a privileged strata of workers, scholars have investigated the ways in which global restructuring creates underprivileged groups of workers, reshaping the hierarchy among women. They also draw attention to structural limitations of global capitalism, which hinder the universalization of waged- 
relations and the promise of well-being by identifying the ways in which the "continued exploitation of the whole of the working class depends upon the marked (i.e., visible) oppression of its weakest members" (Corrigan, 1977: 449).

Recently, an important area of research has investigated the changes in the global division of labor among women by analyzing the recent proliferation of care-work and the transnational migration of care-workers (see HondagneuSotel, 2011 and Herrera, 2013 for a review). Major structural processes associated with global restructuring, such as the increasing participation of middle-class women in developed economies and the withdrawal of the welfare state from care-work provision, have all created a care deficiency in the core countries (Pyle, 2006; Zimerman, Litt, and Bose, 2006). On the other hand, neo-liberal policies that increase poverty in the less developed countries channel third-world women into transnational migration circuits to fill this care deficit (Romero, 1992; Constable, 1997; Parrenas, 2003). Scholars' focus on migration circuits in the analysis of commodification of reproductive labor lays bare the structural-relationality between different types of women's labor on a world scale. Ehrenreich \& Hochschild's (2002) notion of a global care chain identifies patterns in the division of labor by showing how globalization has increasingly extended a chain of women leaving their own families and migrating to wealthier countries where they relieve more privileged women of care-work by taking care of their children and families.

The transfer of work between the first and third worlds reconfigures existing hierarchies among women (Bhattacharyya, Gabriel, and Small, 2001). The increased labor force participation of middle-class women in core countries has been made possible by the increased availability of care-work services. These jobs are disproportionately filled by women of color, African American, Latina, Asian American (Ehrenreich and Hochschild, 2002; Yeates 2009). Drawing on the racial dimension of work transfer, Parrenas (2003) elaborates on the racialized stratification of women in the global era. Her work compares the historical transfer of the care-work from white mothers to African American domestic workers in the US to the current international transfer from employers in northern centers to women from Philippines, Latin America, and the Caribbean.

Inquiries on the Global City ${ }^{4}$ explore structural links between different forms of women's labor as well. Sassen's (2001) study investigates linkages

\footnotetext{
${ }^{4}$ Global cities emerge largely because economic activities get more geographically dispersed in the global era. As this process unfolds, it needs to be centrally controlled. This triggers the formation of a new geography of centrality. Located only in
} 
between economic sectors emerging with global restructuring and multiple forms of labor employed in these sectors. She identifies that the increasing expansion of business services as one of the leading economic sectors goes hand in hand with the downgrading of other economic activities. The fundamental dynamic posited in Sassen's analysis is that producer services put pressure on the larger economy, leading to a polarization in wages of different workers as well as limiting the profit making capacities of various other sectors. Moreover, due to profit-making disparities between producer services and these other sectors, the latter have had to resort to informalization and to downgrading a growing array of economic activities. Thus, for Sassen (2001: 191), global cities emerge as hubs for "the overvalorization of corporate capital and the further devalorization" of disadvantaged economic actors, both firms and workers.

The burgeoning of devalorized economic sectors promotes informalization, a casualization of employment relations, insecure working conditions and low-paying jobs, which are disproportionately filled by women of color (Bhattacharyya, Gabriel and Small, 2001). What furthers the coupling of employment polarization and racialized gender stratification in the global cities, according to Sassen, is the consumption patterns of high-income service workers. A vast supply of low-wage racialized jobs required by high-income gentrification in both its residential and commercial settings and a large array of personal services from expensive restaurants, gourmet shops to special cleaners mushroom in global cities.

For feminist scholars adopting the relational perspective, not only precarious work but also unfree forms of labor are central in the reorganization of labor and class relations in today's global economy. By emphasizing practices of debt-peonage, blackmail, and bonded contract labor, scholars have investigated how women are forced into labor and work as domestic servants, sex workers sweatshop workers, cleaners, beggars etc. (Wang and Chang, 2002; Jeffreys, 2008). These studies reveal that a significant proportion of personal service workers are subjected to various forms of sexual exploitation including prostitution, obscene transactions, bride trading, sex tourism and many others.

By emphasizing the simultaneous expansion of waged-relations with underprivileged labor forms, structural-relational scholars argue that women's well-being cannot be established through waged-work. Notwithstanding the validity of this argument on a world scale, structural relational approaches do

particular cities such as New York, London and Tokyo, global cities emerge as managing posts of the new world economy. 
not take into consideration the contradictory positions in labor structures, nor do they emphasize the significance of partial achievements that women gain by their entry to labor force.

\section{Disempowering Work of Empowerment: Post- Structuralist Feminist Critique}

Post-structural feminist scholars, like world-system scholars, have also challenged the empowerment literature. Focused on the paradoxical results of women's empowerment through waged-work, scholars highlight the ways in which empowerment strategies (paid work) lead to women's disempowerment. Drawing on Foucault's (1984) notion of governmentality, scholars see the emergence of the discourse of empowerment as a key modality of neoliberal self-government and an alternative to more coercive and direct forms of rule (Hindess, 2004). Foucault's insight that power in the form of governing is reflexive on the actions of those governed (that is to say that it acknowledges and utilizes the capacities of those governed and seeks to build new subjectivities) is the departing point for a number of empirical studies on disempowering work of empowerment. Research focusing on neo-liberal employment practices documents how empowerment discourses operate as effective governance practices engraving power relations into women worker's own capacities and subjectivities.

One school of thought highlights the ways that states create discourses of women's empowerment to enhance their own economic competitiveness in the global market. For instance, Guevarra's (2006) research on Philippines' overseas employment program investigates how the state utilizes an empowerment discourse to regulate migrant Filipina workers employed in domestic and entertainment industries by encouraging them to promote a particular public image, a dutiful mother and a chaste woman. Guevarra draws attention to the fact that Philippines' state discourse does not address the structural conditions underlying women's exploitative work situations and displaces the responsibility of protection from the state primarily onto the women. This, Guaverra argues, leads directly to women's disempowerment. Moreover, this discourse reinforces gender inequalities through the glorification of normative gender roles. Thus, Guevarra contends that the state uses the discourse of empowerment as a tool for governing women's roles as citizen-workers whose goal is to be economically competitive for themselves, their families, and their country, thus maintaining a steady influx of dollars into the country. 
Analyses of the labor process open up yet another venue to explore the disempowering effects of empowerment. Recent research on labor control mechanisms investigates the simultaneous production of subjectivities with the production of commodities during the labor process. By using ethnographic fieldwork conducted in Ciudad Juarez, one of Mexico's largest concentrations of maquiladora jobs, Salzinger (2002) elaborates on the production of different subjectivities through practices on the shop floor. She observes that management at four different workplaces constructs four different types of feminine subjectivities. Femininity discourse embodied through daily, mundane, disciplinary policies and practices, she contends, "functions as a constitutive discourse which creates exploitable subjects" and regulates the capitalist production process (Salzinger, 2002: 21).

Amy Hanser's (2008) comparative ethnographic study on Chinese retail settings echoes the dynamics observed by Salzinger regarding the production of femininities and the control over the labor process. Her observations draw attention to the emergence of three groups of women service workers in a globalized economy in China: middle-aged women employed in state-owned department stores, young and unruly women working in clothing bazaars and obedient, young, and attractive women employed in upscale retail stores. Seizing upon differences among women workers in terms of age, body, and femininity, managers in each retail setting secure their position in the consumer market and also discipline women workers.

Another important dimension of the research on these paradoxical results of empowerment addresses new modes of commodity consumption. For many women, new experiences of labor and gender autonomy are often marked by their ability as independent wage earners to participate in new patterns of consumption. Women workers perceive themselves as empowered subjects who catch up with globally oriented standards of modernity, as they constituted themselves as commodity consumers (Mills, 1999; Rofel, 1999; Freeman, 2000). More importantly, pro-woman consumer discourses of the global market facilitate the identification of women's autonomy with a new power to consume. Yet, for many scholars, this points to novel forms power relations through which women are recast into the global market as consumers achieving Western/global commodified beauty standards (Pearson, 2001; Harris, 2004). By reducing the notions of empowerment, choice, and agency to practices of commodity fetishism, scholars contend that pro-woman consumer discourses actually increase women's dependency on the global market (Ganguly-Scrase, 2002; McRobbie, 2009). 


\section{Gender and Globalization Literature}

Literatures addressing gender and globalization recast the question of the relationship between women's well-being and waged-work in the context of complex interactions globalization and gender relations. Many scholars have highlighted the constitutive aspect of gender relations for globalization, arguing that gender -embodied in the sexual division of labor, gender identities, discourses of masculinity and femininity and the like- affect the processes of globalization. Likewise, globalization profoundly shapes gender relations. In this framework, globalization and gender scholars first examine the ways in which gender has been integrated in economics as a central category of analysis and also investigate various aspects in the global economy that illustrate the ways in which those aspects in the global economy interact with the social construction of gender, gender inequality, and women's well-being.

Pivoted on gender as a central category of analysis, recent studies not only illustrate different ways in which the global economy is a gendered process, but also explore how women's subordination could be intensified or decomposed in the context of global restructuring. A wide variety of studies show how particular processes, such as subcontracting (Salzinger, 2003), informalization (Sassen, 1998) and offshoring (Freeman, 2000), have facilitated the incorporation of working-class women into the labor force in developing countries, promoting the feminization of labor. There is, for example, an increased use of home-workers, primarily women, as a response to greater competitive pressures on firms to reduce costs (Hsiung, 1996; Dedeoğlu, 2010). The lower wages paid to home workers and the reduction in overhead costs; while beneficial to firms, turn women into invisible workers (Kümbetoğlu, 2012).

By examining the expanded incorporation of third world women into leading strategic sectors, Saskia Sassen $(1998,2001,2008)$ teases apart the complex relation between gender and the global economy. Of particular significance are the recruitment of women into the new manufacturing and service jobs generated by export-led policies in several Caribbean and Asian countries and the incorporation of large numbers of women and immigrants into the strategic economic sectors in global cities. For Sassen, women workers located in the above-mentioned global sectors emerge as the offshore proletariat, which is identified in stark contrast to the Fordist period's working class that consisted of male industrial workers, earning family wages, enjoying job security, and attached to strong unions that guarantee the increasing wages for workers. The shift from a labor aristocracy to an offshore proletariat, Sassen argues, results from the breaking of the nexus between the condition of being workers in the leading sector of the economy and constituting a labor 
aristocracy. The way women are incorporated into the leading industries renders them invisible and thus constitutes them as a disempowered class of workers in the service of global strategic sectors. In this sense women and immigrants emerge as the systemic equivalent of the offshore proletariat.

Despite the emphasis on the subordination of women in terms of class dynamics, Sassen's work also acknowledges the opportunities that women make use of as they are incorporated into the global labor force. Concurring with the basic findings of the empowerment literature, Sassen notes that women gain greater personal autonomy and independence during this process. She also underlines the fact that women gain more control over budgeting and other domestic decisions and greater leverage in requesting help from men in domestic chores. Moreover, their access to public services and other public resources gives them a chance to become incorporated into the mainstream society.

In the early 2000s, studies extended beyond the mere acknowledgment of opportunities that women gain and instead incorporated a more sophisticated approach investigating both opportunities and power relations affecting women workers. Beneria's (2003) inquiry on globalization and gender captures precisely this point. She contends that it is difficult to generalize about the effects of global economic restructuring on women's employment given that there are contradictory forces at work. On the positive side, she highlights the improvement in women's educational levels across countries and the preference for women's labor. However, she underlines that the employment conditions are often accompanied with greater insecurity of women's jobs in comparison with men's, even though all jobs in general are becoming less secure. Thus, she offers an analysis of globalization with gender dimensions that reveals contested implications rather than monolithic or universal claims for the transformation of gender relations. Dedeoğlu's (2010) study on the feminization of garment work in Turkey illustrates complex and contradictory outcomes of waged-work for women in the context of global reconstruction. Focused on women working at small family workshops and homes for exportoriented industries, her research shows that women acquire a certain degree of independence and bargaining power both at home, such as power to refuse arranged marriages and at workplace, such as power to control the labor process. On the other hand, women are intensively subordinated to working conditions that characterize the Turkish garment industry such as long hours, low pay, and lack of social protection. Besides, working at home reinforces conservative gender hierarchies, underlining women's roles as housewives or mothers. 
The emphasis on the contradictory impact of global processes on gender relations have provided some opening for a consideration of the ways in which race, class and ethnicity have transformed and complicated gendered hierarchies in the making of globalization. The intersectionality approach, emphasizing the simultaneous and multiple oppressions of gender, race and class, offers a theoretically sophisticated methodology to explore the dynamics and contradictory workings of power (Maynard, 1994; Collins, 1999; YuvalDavis, 2006; Patil, 2013).

Hite and Viterna's (2005) study on the Latin American working classes illustrates the contradictory workings in the global era. Investigating how double processes of global economic restructuring and adjustment programs have reorganized class structures and gender hierarchies in the region, they show that women's parity with men in terms of class position (occupation and income) has increased during the past two decades, with women making inroads to the historically male-dominated formal proletariat. Nevertheless, they argue that women's parity with men largely derives from the deterioration of men's status in the class structures. As men experience occupational downgrading under neo-liberal restructuring, their working conditions become increasingly similar to women's.

In a comparative study on the changing dynamics of the labor force in the US and Mexico, Fernandez-Kelly (2008) notes a similar transformation. She specifically addresses the disappearance of the family wage and its impact on class formation. She writes, "The disappearance of the family wage entails a new expectation that all workers, regardless of ascribed characteristics or domestic involvement, will assume responsibility for the maintenance of at least one person: himself or herself" (2008: 401). Such is a janus-faced transformation: on the one hand, as women increasingly engage in waged work, they face the promise of autonomy and economic self-reliance, on the other hand, a greater atomization or individuation of the labor force in terms of gender weakens class structures as well as class-based collectivities.

Interest in the global labor process has stimulated analyses on complex entanglements of gender, race, class, and ethnicity. Scholars focusing on labor control mechanisms explore the ways in which the labor process is gendered, racialized and ethnicized, a strategy actively constructed by employment or management policies in order to facilitate capital accumulation (Kang, 2003; Barker and Feiner, 2009; Sarioglu 2013). Otis' (2011) study on Chinese hotels features different types of managerial strategies for the labor control. In order to distinguish themselves from the plethora of neighboring Chinese hotels and to increase their position in the market, management not only promotes certain 
sexualized images of women workers, it also adopts regional labor hierarchies, especially with regard to race and ethnicity

Another comparative analysis on the labor process explores how different social constructions of reproductive work are strategically used by employers to discipline Guatemalan women workers. Menjivar (2006), focusing on working conditions of Guatemalan women in both Guatemala and Los Angeles, investigates how women's working conditions vary in accordance with their assumed responsibilities regarding household chores. Employers making use of historically and culturally constructed notions of housework respectively in the US and Guatemala, assign differential tasks to women, intensifying the working hours.

Studies have also examined the impact of race and gender on the recruitment of women into service jobs by looking at many new workplace sites produced by global economic restructuring (McDermott, 2006; Williams, 2006; Sherman, 2007). These studies show that the interplay of gender, race and class has intensified the process of women's marginalization within service work. For example, in her Class Acts: Service and Inequality in Luxury Hotels, Rachel Sherman (2007) demonstrates how hotel work in the United States has developed along racial lines: while workers whose jobs require interaction with customers are usually white, non-interactive workers behind the scenes are typically U.S. women of color or immigrants.

Intersectionality as an approach to study inseparable and interlocking relations among categories of race, gender, and ethnicity, in turn leads to a concern with subjectivity and identity (Maynard, 1999). bell hook's (1991) call for the incorporation of the difference of experience has prompted scholars to explore complexity of working class feminine identities emerging as a result of global restructuring. Further, scholars investigate how these new identities shift traditional power relations and open up new opportunities for women, simultaneously creating new power relations. Given that the management of the self is central to the organization of service work, a plethora of studies have focused on the production of gendered selves at the service workplaces, specifically the ways that service workers generate speech, action, emotion, manners and looks as they fulfill their job requirements. Studies on the hospitality (Warhurst and Nickson, 2007) and retail sectors (Williams and Connell, 2010) demonstrate how hiring and managerial strategies to control the service work rely on norms regarding femininity, thereby shaping workers' gendered selves in certain ways. The airline industry (Hochschild, 1983), for instance, uses norms of western middle-class femininity to train female flight attendants, while in an upscale retail store in the United States, (Gatta, 2011), women sales assistants are expected to exude an air of youthful, glamorous 
femininity. Managers utilize a variety of strategies, including scripts and codes of behavior and speech, to regulate these workers' selves. As a result, women service workers produce certain versions of femininity, such as maternal, youthful and exotic femininities, as a part of their jobs.

By drawing on the decomposition of existing class structures, some scholars examine how global economic integration is giving way to new historical subjects with characteristics that deviate significantly from older counterparts. Pun (2005) research on women factory workers in Shenzhen, China during globalization, depicts a portrait of women workers significantly different than the formal proletariat of the previous period. In the world's largest sweatshop, as Pun calls it, dagongmei (working girls) from the Chinese countryside follow dreams of freedom and excitement before returning to their villages to become wives, are not members of a new urban proletariat forged by globalization but an itinerant workforce whose labor is not recognized in class terms. In historical-structural terms, the dagongmei are members of an international proletariat. Nevertheless, gender, age, and rural provenance render them invisible in class terms.

As the emphasis was placed on the emergence of non-class identities in the global era, emphasis in the literature has shifted towards exploring complexities in women's lives that cannot be charted under the subordination of women perspectives (Chua, Bhavnani, and Foran, 2000; Singh, 2007; Siddiqi, 2009). In its initial period, gender and globalization studies mostly focused on the exploitation of women by multinational capital and its ability to take advantage of female stereotypes associated with women workers: docility, nimble fingers, youth, often of rural origins from developing countries acceptance of low wages and poor working conditions (Lim, 1984). This analysis mainly relied on a simplistic Marxist-feminist approach that disregards the complexities of historical-social formations and thus reflected an overarching view of women as victims. Nevertheless, this initial period is gradually replaced by an analysis of women's waged-work that captures the complexities and the often contradictory effects of global restructuring. Various authors began to point out the ways in which women were not merely passive victims of exploitative conditions, illustrating instead the multiplicity of factors that affected their incorporation in paid work (Lim, 1997).

One of the most striking examples of this new approach addresses the women working in sex industries (Kempadoo, Sanghera, and Pattanaik 2005; Reitzer 2007). Instead of depicting sex workers as victims, recent studies tend to elaborate more on the economic constraints for women sex workers, their families and their communities. This approach to sex work emphasizes the conditions of the women's work and their lives: demeaning treatment by clients 
and supervisors, extreme exploitation, usually conducting services without their full consent under conditions of slavery and blackmail, treatment of physical violence and abuse, occupational health hazards and concerns, and highly inadequate support for health care and mental health services (Kempadoo, Sanghera, and Pattanaik, 2005; Zengin 2011). The key avenue of agency for this group of women, within this approach, involves collective struggle and unionization (Kempadoo, 2003; Hardy, 2010).

Drawing on theories of de-traditionalization and individualization (Giddens, 1991; Beck, 1992), scholars further investigate how employment in global era transforms traditional positioning of women vis-à-vis state and social institutions. For example, in her study on China, Xiaojiang (2005) argues that global restructuring offers women an unexpected opportunity to cast off the entanglements of nationalism, family, clan, and community. Drawing on the fact that women turn down housewifery and opt for waged-work at foreign enterprises despite the exploitative working conditions and low-wages, Xiaojiang maintains that the degree of self-autonomy that comes with wagedwork is much greater than those allowed in traditional social life. She argues that prior to the era of globalization women were contained within national or state-centric projects. Nevertheless, global restructuring offers a historical opportunity for women's liberation via a "fortuitous process of individuation" (Xiaojiang 2005: 122). In a similar vein, Walker's (2014) research on workingclass young women in St. Petersburg, Russia, illustrates the opportunities available to young women through higher education and service employment in the context of global neoliberalism. Despite the limited advancement prospects offered by new service jobs, young women in Petersburg choose working at service occupations over old manufacturing jobs, derive significant value from these new opportunities, and use job-related resources to construct narratives of self-actualization which enable them to approximate the image of respectable femininity.

Under these conditions, women have the power to negotiate the conventional gender roles and identities ascribed on them. Cupples' (2005) research on working single mothers in Nicaragua explains how neo-liberal restructuring provides some opening for the negotiation of gendered identities. Her observations indicate that women's participation in the labor market, although crucial for family survival, is not devoid of personal ambition. Despite the constraints of the neo-liberal economic structuring and hegemonic constructions of domestic motherhood that poses challenges for women's right to work, women increasingly perceive employment as a central aspect of their lives and a means to personal self-improvement. Specifically, work-life can, over time, bring about shifts in understandings of family and motherhood because home and the site of waged work are not separate entities but are 
mutually constituted in women's lives. Thus, single mothers simultaneously absorb and challenge discourses of domestic femininity.

\section{Discussion \& Conclusion}

The literature addressing globalization and gender explores complex interactions between global processes, women's work, and well-being. In doing so, recent studies highlight contradictory processes involved in global restructuring that simultaneously subordinate women and open up novel opportunities for them. Recent works also embrace identity, sexuality, and discourse as essential foci for investigation and analysis. More importantly perhaps, recent scholarship has shifted away from women-as-victims approach and has focused instead on women's agency in constructing their identities and challenging oppressive hierarchies of race, class, and sexuality.

Within these recent works, four major areas of inquiry can be distinguished, each of which offers different answers to the question of how incorporation into waged-work affects women's well-being. First, the human development approach draws attention to the benefits of global restructuring for women. Proponents of this view hold that waged-work enables women to expand their realm of opportunity and choice while breaking down traditional forms of authority and challenging conventional ideas about gender roles and expectations. Secondly, scholars adopting a structural-relational perspective argue that instances of women's empowerment through wage-work are bound to be partial and cannot be universalized given that capitalism as a world market phenomenon structurally creates marginal masses workers and varied levels of coercion-based social conditions for women workers. Third, poststructural feminist critiques also challenge the capabilities approach by documenting the novel ways by which women's capacities, subjectivities, and conduct are governed and regulated with the incorporation of women to the global labor force. Finally, by focusing on the contradictions and conflicts generated by the global restructuring process, globalization and gender scholars have attempted to uncover the multifaceted dimensions of women's wagedwork experiences, demonstrating the complex interplay between women's empowerment and disempowerment.

Each of these approaches has its distinct conceptual designation for the notion of well-being: For Engels it was the formal proletariat's interests defined in contradiction solely with the capitalists, for human development approach it is a specific interpretation of Marx's notion of human capacities, for liberal feminists it is largely women's increasing parity with men, and for feminist human development scholars it is the empowerment of women, and for the post-structural feminists it is subversion of the multiplicity of subject 
positions that women, as bearers of classed, racialized, national, ethnic, sexual, and aged as well as gendered identities, occupy in relation both to men and to each other.

Together, the four different literatures examine effectively the political, social, and cultural dimensions of the concept of well-being. However, the emotional dimension of well-being remains poorly addressed. ${ }^{5}$ In recent decades, the study of emotions has become increasingly central to sociology, with a growing number of scholars incorporating the study of emotion into their theories and research agendas (Turner, 2010). Furthermore, scholars widely acknowledge that emotions have been significant area for the study work and employment (Wharton, 2009; Lopez, 2010; Hanser 2012). In particular, the theoretical framework of emotion that Collins developed gives a lens through which to understand inequality, stratification status and power. For Collins, "Privilege and power is not simply a result of unequal material and cultural resources. It is a flow of emotional energy across situations" (2004: xiii). Indeed, recent research suggests that there are important linkages to be made between emotions and different forms of stratification, including race, gender, and class (Turner, 2010; Hanser, 2012). Incorporating the insights offered by sociological inquiry on emotion into the field of women's wellbeing and waged-work might help scholars examine how women employed in low-wage sectors of global economy react emotionally to their place in the larger stratification system and in negotiating their share of material as well as cultural resources. Turning the spotlight onto these issues can also illuminate an array of workplace dynamics, including the reproduction of authority and inequality. Last but not least, an analysis of women's emotional experiences at work can generate insights about cultural/psychological processes related to women's well-being.

\footnotetext{
${ }^{5}$ To be sure, scholars adopting Post-structuralist approaches emphasize that subjectivities are continuously shaped by emotions, affect, and desire. However, the role of emotions have been somewhat neglected in previous research on waged-work and women's well-being in global restructuring. I would like to thank you to an anonymous referee for bringing this point to my attention.
} 


\section{References}

Agarwal, Bina (1997), "Bargaining and Gender Relations: Within and beyond the Household Food Consumption and Nutrition Division", Discussion Paper No. 27. International Food Policy Research Institute.

Barker, Drucialla K. and Susan F. Feiner. (2009), "Affect, Race, and Class: An Interpretative Reading of Caring Labor", Frontiers: A Journal of Women Studies, 30 (1): 41-54.

Beck, Ulrich (1992), Risk Society: Towards a New Modernity (London: Sage Press).

Beneria, Lourdes (2003), Gender, Development, and Globalization: Economics as if People Mattered (New York: Routledge).

Bennholdt-Thomsen, Veronika (1984), "Towards a Theory of the Sexual Division of Labour", Smith, Joan, Immanuel Wallerstein, Hans Dieter-Evers (eds.), Households and the WorldEconomy (London: Sage Press).

Bespinar, Umut (2010), "Questioning Agency and Empowerment: Women's Work-Related Strategies and Social Class in Urban Turkey", Women's Studies International Forum, 33: 523-532.

Beutelspacher, Austraberta Nazar, Emma Zapata Martelo, Veroniqa Vazquez Garcia (2005) "Does Contraception Benefit Women? Structure, Agency, and Well-being in Rural Mexico", Agarwal, Bina, Jane Humpries, Ingrid Robeyns (eds.), Amartya Sen's Work and Ideas: A gender perspective (London, New York: Routledge): 215-240.

Bhattacharyya, Gargi, John Gabriel, and Stephen Small (2001), Race and Power (New York and London: Routledge)

Butler, Judith (1990), Gender Trouble: Feminism and the Subversion of Identity (New York and London: Routledge).

Caffentzis, George (1999), "The End of Work or the Renaissance of Slavery? A Critique of Rifkin and Negri," Common Sense: Journal of the Edinburgh Conference of Socialist Economists, no. 24 (December, 1999): 20-38; reprinted in Multitudes Web (2005), on-line at: http://multitudes.samizdat.net/The-End-of-Work-or-the-Renaissance.

Chua, Peter, Kum-Kum Bhavnani, and John Foran (2000), "Women, Culture, Development: a New Paradigm for Development Studies", Ethnic and Racial Studies Journal, 23: 820-41.

Clark, CD (2001) "Foreign Marriage, 'Tradition', and the Politics of Border Crossings" Chen, NN, CD Clark, SZ. Gottschang, L. Jeffrey (eds.), China Urban: Ethnographies of Contemporary Culture. (Durham, NC: Duke University Press).

Collins, Patricia Hill (1999), "Moving Beyond Gender: Intersectionality and Scientific Knowledge", Myra Marx Ferree, Judith Lorber, and Beth Hess (eds.), Revisioning Gender (Sage Press): 261-284

Collins, Randall (2004), Interaction Ritual Chains (Princeton, NJ: Princeton University Press).

Constable, Nicole (1997), Maid to Order in Hong Kong: An Ethnography of Filipina Workers. (Ithaca, NY: Cornell Univ. Press).

Corrigan, Philip (1977), "Feudal Relics or Capitalist Monuments? Notes on the Sociology of Unfree Labour", Sociology, 11 (3): 435-463.

Cupples, Julie (2005), "Love and Money in an Age of Neoliberalism: Gender, Work, and Single Motherhood in Postrevolutionary Nicaragua", Environment and Planning 37: 305-322.

Dedeoğlu Saniye (2010), "Visible Hands - Invisible Women: Garment Production in Turkey", Feminist Economics, 16 (4): 1-32. 
Engels, Freidrich. (1844, 1972). The Origin of the Family, Private Property, and the State, in the Light of the Researches of Lewis H. Morgan. (New York: International Publishers).

Ehrenreich, Barbara and Arlie R Hochschild (2002), Global Woman: Nannies, Maids and Sex Workers in the New Economy (New York: Metropolitan Books).

Federici, Silvia (2008) "Precarious Labor: A Feminist Viewpoint" Upping the Ant; on-line at: http://auto_sol.tao.ca/node/3074.

Feldman, Shelley (2005), "Social Development, Capabilities, and the Contradictions of (Capitalist) Development", Draft paper for the MSU Conference on Ethics and Development, Michigan State University, East Lansing, MI.

Feldman, Shelley and Paul Gellert (2006), "The Seductive Quality of Central Human Capabilities: Sociological Insights into Nussbaum and Sen's disagreement”, Economy and Society 35. 423-452.

Fernández-Kelly, Patricia. (2008), "Gender and Economic Change in the United States and Mexico, 1900-2000”, American Behavioral Scientist 52: 377-404.

Foucault, Michel. (1991), Governmentality. In Burchel, G., Gordon, C., Miller, P. The Foucault effect: Studies in Governmentality. London: Harvester-Wheatsheaf.

Frankenberg, Elizabeth and Duncan Thomas (2001) "Measuring Power: Food Consumption and Nutrition Division" Discussion Paper No. 113. Washington DC: International Food Policy Research Institute.

Freeman, Carla (2000), High Tech and High Heels in the Global Economy: Women, Work and Pink-Collar Identities in the Caribbean (Durham, NC: Duke University Press).

Gage, A.J. (1995), "Women's Socioeconomic Position and Contraceptive Behavior in Togo", Studies in Family Planning 26: 264-277.

Ganguly-Scrase, Ruchira. (2002), "Renegotiating boundaries: Self perception and public debate on globalization and gender equality in India" Asian Journal of Women's Studies, 8: 58-100.

Gatta, Mary. 2011. "In the 'Blink' of an eye - American High-End Small Retail Businesses and the Public Workforce System", Grugulis, Irena and Ödül Bozkurt (eds), Retail Work (Critical Perspectives on Work and Employment) (Palgrave Macmillan)

Giddens Anthony (1991), Modernity and Self-identity: Self and Society in the Late Modern Age (Oxford: Polity Press).

Guevarra, A. Romina (2006), "Managing 'vulnerabilities' and 'empowering' migrant Filipina workers: The Philippines' overseas employment program”, Social Identities 12. 523-541.

Hanser, Amy (2008), Service Encounters: Class, Gender and the Market for Social Distinction in Urban China (Stanford,CA: Stanford University Press).

Hardy, Kate (2010) "Gendered Activism and the Politics of Women's Work Incorporating Sex Workers into the Argentine Labor Movement", International Labor and Working-Class History 77 (01): 89-108.

Harris, Anita (2004), Future Girl: Young Women in the Twenty-First Century (New York and London: Routledge Press).

Hanser, Amy (2012), "Class and the Service Encounter: New Approaches to Inequality in the Service Work-place”, Sociology Compass 6(4): 293-305.

Herrera, Gioconda (2013), “Gender and International Migration: Contributions and CrossFertilizations", Annual Review of Sociology 39: 471-89. 
Hill, Marianne T. (2005), "Develeopment as freedom", Agarwal, Bina, Jane Humpries, Ingrid Robeyns (eds.), Amartya Sen's Work and Ideas: A gender perspective (London, New York: Routledge): 119-138.

Hindness, Barry. (2004) "Liberalism- What's in a name?" Larner, Wendy and William Walters (eds.), Global Governmentality: Governing International Spaces (London: Routledge): 23-39.

Hite, Amy Bellone and Jocelyn S. Viterna (2005), "Gendering Class in Latin America: How Women Effect and Experience Change in the Class Structure", Latin American Research Review 40: $50-82$.

Hochschild, Arlie (1983), The Managed Heart: Commercialization of Human Feeling (Berkeley: University of California Press)

Hondagneu-Sotelo Pierrette. (2011), "Gender and migration scholarship: an overview from a 21st century perspective". Migr. Int. 6(1):219-33

hooks, bell (1991), Yearning: Race, Gender, and Cultural Politics (Boston: South End Press).

Hsiung, Ping-Chun. (1996) Living Rooms as Factories: Class, Gender, and the Satellite Factory System in Taiwan. (Philadelphia: Temple University Press).

Jejeebhoy, Shireen J. (2000), "Women's Autonomy in Rural India: Its Dimensions, Determinants, and the Influence of Context", Presser, Harriet and Gita Sen (eds.), Women's Empowerment and Demographic Processes: Moving beyond Cairo. (New York: Oxford University Press)

Jejeebhoy, Shireen J.and Zeba A. Sathar (2001), "Women's Autonomy in India and Pakistan: The Influence of Religion and Region" Population and Development Review 27: 687-712.

Jeffreys, Sheila (2008), The Industrial Vagina: The Political Economy of the Global Sex Trade (Routledge Press).

Kabeer, Naila (1999), "Resources, Agency, Achievements: Reflections on the Measurement of Women's Empowerment", Development and Change 30: 435-464.

Kabeer, Naila (2001), The Power to Choose: Bangladeshi Women and Labour market Decisions in London and Dhaka (London/NewYork: Verso).

Kang, Miliann. (2003), "The Managed Hand: The Commercialization of Bodies and Emotions in Korean Immigrant-owned Nail Salons", Gender \& Society 17 (6): 820-39.

Kantor, Paula. (2009), "Women's Exclusion and Unfavorable Inclusion in Informal Employment in Lucknow, India: Barriers to Voice and Livelihood Security", World Development 37: 194207.

Kapadia, Karin (1995), "The Profitability of Bonded Labour: The Gem-Cutting Industry in Rural South India," Journal of Peasant Studies, 22(3): 446-483.

Kempadoo, Kemala. (2003), "Globalizing Sex Workers' Rights" Canadian Women's Studies 22 $(3,4): 143-150$.

Kempadoo, Kemala, Jyoti Sanghera, and Badanna Pattanaik (eds.) (2005), Trafficking and Prostitution Reconsidered: New Perspectives on Migration, Sex Work and Human Rights, (Paradigm Publishers).

Keyder, Caglar (2005), "Globalization and Social Exclusion in Istanbul", International Journal of Urban and Regional Research, 29(1): 124-134.

Kümbetoğlu Belkıs. (2012) "Görünmeyen Sektörün İşçileri ve Sağlık Sorunları: Bir Uygulama Projesinin Düşündürdükleri”, Kadın Araştırmaları Dergisi, (5): 63-74. 
Lopez, Steven Henry (2010), 'Workers, Managers, and Customers: Triangles of Power in Work Communities" Work and Occupations 37: 251-71.

Lynch, Caitrin (1999). "The "Good Girls" of Sri Lankan Modernity: Moral Orders of Nationalism and Capitalism”, Identities 6: 55-89.

Lim, Linda (1984), "Capitalism, Imperialism, and Patriarchy: The Dilemma of Third-World Women Workers in Multinational Factories", Nash, June and Patricia Fernandez-Kelly (eds.), Women Men and International Division of Labor. (Albany: SUNY Press): 70-91

Lim, Linda. (1990). "Women's Work in Export Factories: The Politics of a Cause", Tinker Irene (ed.), Persistent Inequalities: Women and World Development. (New York: Oxford University Press): 213-34.

Malhotra, Anju and Mark Mather (1997), "Do Schooling and Work Empower Women in Developing Countries? Gender and Domestic Decisions in Sri Lanka”, Sociological Forum 12: 599630.

Malhotra, Anju, Sidney Schuler, Carol Boender (2002), "Measuring Women's Empowerment as a Variable in International Development" Background Paper Prepared for the World Bank Workshop on Poverty and Gender: New Perspectives.

Mason, K. and HL Smith (2000), "Husbands' versus Wives Fertility Goals and Use of Contraception: The Influence of Gender Context in Five Asian Countries", Demography 37: 299-311.

Maynard, Mary (1994) "'Race,' Gender, and the Concept of 'Difference' in Feminist Thought," Afshar, Haleh and Mary Maynard (eds.), The Dynamics of "Race" and Gender (Taylor and Francis).

Mayoux, Linda. (2001), “Tackling the Down Side: Social Capital, Women's Empowerment and Micro-Finance in Cameroon", Development and Change 32: 435-464.

McDermott, Monica. (2006), Working Class White: the Making and Unmaking of Race Relations. (Berkeley: University of California Press)

McRobbie, Angela (2009), The Aftermath of Feminism: Gender, Culture, and Social Change. (London: Sage Press).

Menjivar, Cecilia (2006), “Global Processes and Local Lives: Guatemalan Women's Work and Gender Relations at Home and Abroad" International Labor and Working-Class History 70: 86-105.

Mies, Maria, Veronika Bennholdt-Thomsen, and Claudia von Werholf (1988), Women: The Last Colony (Zed Press).

Mills Mary Beth (1999), Thai Women in the Global Labor Force: Consuming Desires, Contested Selves, (New Brunswick, NJ, Rutgers University Press.)

Mohanty, Chandra Talpade (2003), “'Under Western Eyes' Revisited: Feminist Solidarity through Anticapitalist Struggles", Signs, 28(2): 499-535.

Murphy-Graham, Erin (2008), “Opening the Black Box: Women's Empowerment and Innovative Secondary Education in Honduras", Gender and Education 20: 31-50.

Otis, Eileen. (2011) Markets and Bodies: Women, Service Work, and the Making of Inequality in China. [E-reader version] Retrieved from http://www.amazon.com.

Parrenas, Rhacel Salazar (2003), The Globalization of Care: Patriarchal Households and Regressive State Regimes in the New Economy (New York City, Hunter College: University Lecture Series) 
Patil, Vrushali. (2013), "From Patriarchy to Intersectionality: A Transnational Feminist Assessment of How Far We've Really Come", Signs, 38(4): 847-867.

Pearson, Ruth (2001), "All Change? Men, Women Reproductive Work in the Global Economy" Jackson, Cecile (ed.), Men at Work: Labor, Masculinities and Development (London: Routledge Press).

Pearson, Ruth. (2004, "Women, Work, and Empowerment in a Global Era" IDS Bulletin 35: 117-20.

Peterson, V. Spike (2003), A Critical Rewriting of Global Political Economy (New York and London: Routledge).

Pyle, Jean L (2006), "Globalization and the Increase in Transnational Care Work: The Flip Side" Globalizations 3(3): 297-315.

Portes, Alejandro (2004), "The Free Market City: Latin American Urbanization in the Years of Neoliberal Adjustment", Paper prepared for the project Latin American Urbanization at the End of the Twentieth Century, sponsored by the Andrew W. Mellon Foundation.

Pun, Ngai. (2005) Made in China: Women Factory Workers in a Global Workplace (Durham: Duke University Press; Hong Kong: Hong Kong University Press).

Rathgeber, Eva M. (1990), "WID, WAD, GAD: Trends in Research and Practice", The Journal of Developing Areas 24: 489-502.

Razavi, Shahra. and Carol Miller (1995), "From WID to GAD: Conceptual Shifts in the Women and Development Discourse", U.N. Fourth Conference on Women Occasional Paper, no. 1, Geneva: United Nations Research Institute for Social Development.

Razavi, Shahra (2007), "Does Paid Work Enhance Women's Access to Welfare? Evidence from Selected Industrializing Countries", Social Politics (14): 58-92.

Rofel, Lisa. (1999), Other Modernities: Gendered Yearnings in China after Socialism. (Berkeley: University of California Press.)

Romero, Mary. (1992), Maid in the U.S.A (London/New York: Routledge)

Sarioglu, Esra. (2013), "Gendering the Organization of Home-Based Work in Turkey: Classical versus Familial Patriarchy", Gender, Work \& Organization 20 (5): 479-497.

Sassen, Saskia. (2008), "Two Stops in Today's New Global Geographies: Shaping Novel Labor Supplies and Employment Regimes", American Behavioral Scientist 52: 457-496.

Sassen, Saskia. (1998), Globalization and its Discontents: Essays on the New Mobility of People and Money (New York: New Press).

Sassen, Saskia. (2001), The Global City: New York, London, Tokyo. (Princeton, N.J: Princeton University Press).

Seguino, Stephanie. (2006), "The Great Equalizer? Globalization Effects on Gender Equity in Wellbeing in Latin America and the Caribbean" Shaikh, Anwar (ed.), Globalization and the Myths of Free Trade (New York and London: Routledge): 177 - 214.

Scott, Joan Wallace. (1992), "Experience" Butler, Judith and Joan Wallace Scott (eds.), Feminists Theorize the Political (New York: Routledge): 22-40.

Salzinger, Leslie (2003), Genders in Production: Making Workers in Mexico's Global Factories (CA: University of California Press).

Sen, Amartya (1988), "Development as Capabilities Expansion”. Journal of Development Planning 19: 41-58.

Sen, Amartya (1999), Development as Freedom (New York: Anchor). 
United Nations Development Programme (2000), Human Development Report (New York. Oxford University Press)

Sherman, Rachel (2007), Class Acts: Service and Inequality in Luxury Hotels (University of California Press, Berkeley).

Siddiqi, Dina M. 2009, "Do Bangladeshi Factory Workers Need Saving? Sisterhood in the PostSweatshop Era" Feminist Review 91: 154-174.

Singh, Shweta (2007), "Deconstructing 'Gender and Development' for 'Identities of Women'", International Journal of Social Welfare, 16: 100-109.

Shin, Hae Ran (2008), "A New Insight Into Urban Poverty: The Culture of Capability Poverty amongst Korean Immigrant Women in Los Angeles", Urban Studies 45: 871-896.

Standing, Guy (2009), Work After Globalization: Building Occupational Citizenship (Northampton MA: Edward Elgar Press).

Tinker, Irene (1990). "The Making of a Field: Advocates, Practitioners, and Scholars", Tinker, Irene (ed.), Persistent Inequalities: Women and World Development (New York: Oxford University Press): 123-49.

Turner, Jonathan H. (2010), "The Stratification of Emotions: Some Preliminary Generalizations", Sociological Inquiry, 80: 168-99.

Wang, Hong-zen and Shu-ming Chang (2002), "The Commodification of International Marriages: Cross-border Marriage Business in Taiwan and Viet Nam", International Migration, 40 (6): 93-116.

Warhurst, Chris and Dennis Nickson (2007), "Employee Experience of Aesthetic Labor in Retail and Hospitality" Work, Employment and Society, 21(1): 103-120.

Weitzer, Ronald (2007), "Prostitution as a Form of Work”, Sociology Compass, 1 (1): 143-155.

Whitson, Risa (2010), "'The Reality of Today Has Required Us to Change': Negotiating Gender Through Informal Work in Contemporary Argentina", Annals of the Association of American Geographers, 100 (1): 159-181.

Williams, Christine L. (2006), Inside Toyland: Working, Shopping, and Social Inequality (Berkeley: University of California Press).

Williams, Christine L. and Catherina Connell (2010), "Looking Good and Sounding Right: Aesthetic Labor and Social Inequality in the Retail Industry", Work and Occupations 37 (3): 349-77.

Wolf, Diane L. (1992), Factory Daughters: Gender, Household Dynamics, and Rural Industrialization in Java (Berkeley: University California Press)

Xiaojiang, L. (2005). “From 'Modernization' to ‘Globalization': Where are Chinese Women?”, Signs 26: $114-45$

Yeates, Nicola (2009), Globalizing Care Economies and Migrant Workers: Explorations in Global Care Chains (New York: Palgrave Macmillan).

Yuval-Davis, Nira (2006), "Intersectionality and Feminist Politics", European Journal of Women's Studies, 13 (3): 193-209.

Zengin, Asli (2011) iktidarın Mahremiyeti: İstanbul'da Hayat Kadınları, Seks Işçiliği, ve Şiddet. (Istanbul: Metis Yayınları).

Zimmerman, Mary, Jacquelyn Litt, and Christine Bose (eds.) (2006), Global Dimensions of Gender and Carework (CA: Stanford University Press). 